\title{
Clear-Cell Adenocarcinoma of the Gallbladder with Alpha-Fetoprotein Production: A Case Report and Review of the Literature
}

\author{
Nutan Dixit ${ }^{\mathrm{a}}$ Shalini Trivedi ${ }^{\mathrm{a}}$ Vikas Kumar Bansal $^{\mathrm{b}}$ \\ aDepartment of Pathology, Indira Gandhi ESI Hospital, Delhi, India; ' Department of Urology, \\ Indraprashtha Apollo Hospital, Delhi, India
}

\section{Keywords}

Gallbladder · Clear-cell carcinoma · Alpha-fetoprotein

\begin{abstract}
Gallbladder tumors are the fifth most common cancers of the gastrointestinal tract with poor prognosis and low survival. The most common type is adenocarcinoma of which the clear cell type is an unusual histologic variant with alphafetoprotein (AFP)-producing gallbladder carcinoma, reported extremely rarely, which makes the index case an uncommon entity. AFP secretion by gallbladder carcinomas may occur given the similar embryological origin of liver and gallbladder. Herein we report a case of an incidental carcinoma of the gallbladder in a 60-year-old woman with an elevated serum AFP concentration at presentation, who underwent cholecystectomy for cholelithiasis and was rendered the diagnosis of AFP-producing clear cell carcinoma of the gallbladder through histopathology and immunohistochemistry. Her postoperative laboratory tests showed a decline in AFP levels to normal respectively. The clinical and pathologic importance of AFP production by clear-cell adenocarcinoma of the gallbladder (CCG) has thus far remained completely obscure. However, we must recognize the entity of this
\end{abstract}

karger@karger.com www.karger.com/gat

Karger $\stackrel{\text { ' }}{5}$

GOPEN ACCESS
(C) 2021 The Author(s)

Published by S. Karger AG, Basel

This article is licensed under the Creative Commons AttributionNonCommercial-NoDerivatives 4.0 International License (CC BYNC-ND) (http://www.karger.com/Services/OpenAccessLicense). Usage and distribution for commercial purposes as well as any distribution of modified material requires written permission. tumor because accurate and early diagnosis of CCG is imperative to avoid misdiagnosis as possible secondary metastasis and consequent delay in appropriate surgical intervention. Relevant medical history of a patient, various imaging studies, foci of classical adenocarcinoma within the tumor, and an efficient immunohistochemical panel can be informative and assist in arriving at an accurate diagnosis.

(c) 2021 The Author(s)

Published by S. Karger AG, Basel

\section{Introduction}

Gallbladder cancer is the most common malignant as well as the most aggressive cancer of the biliary tract with poor prognosis and very low overall 5-year survival rates of $<5 \%[1,2]$. This carcinoma is more common in some developing countries and infrequent in developed countries with a peculiar geographical variation and significant differences in certain ethnicities. Indo-Gangetic belt, particularly northern India, Mapuche Indians in Chile, and South America are the most affected areas [3]. The most common histological type is adenocarcinoma, accounting for $98 \%$ of all gallbladder malignancy of which the clear-cell variant is exceedingly rare and is often iden- 


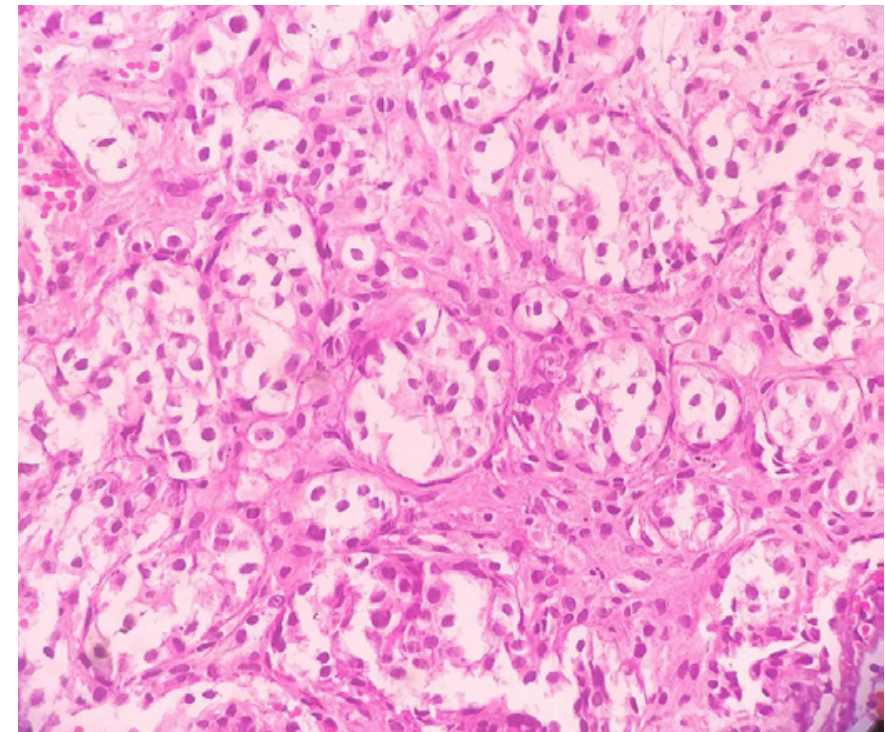

Fig. 1. Photomicrograph showing tumor cells organized in nests with clear cytoplasm, well-defined cytoplasmic borders, little cytological atypia, and hyperchromatic nuclei $(\mathrm{H} \& \mathrm{E}, \times 400)$.

tified with foci of classical adenocarcinoma, adenosquamous carcinoma, or mucinous carcinoma [4]. Clear-cell adenocarcinoma of the gallbladder (CCG) can give rise to diagnostic difficulties with secondary focuses having similar morphology, especially the metastasis from renal-cell carcinoma. Very little is known regarding the pathological prognostication of the clear-cell variant due to rare cases reported in the literature and possible misinterpretation as metastatic deposits [5].

Serum alpha-fetoprotein (AFP) levels are often remarkably increased in hepatocellular carcinomas and yolk sac tumors. An elevated serum AFP concentration can also be perceived in carcinoma of the gastrointestinal tract, pancreas, lung, kidney, and so on, but AFP-producing gallbladder carcinoma (GBC) is reported extremely rare $[6,7]$. We hereby present a case of AFP-producing CCG, which, to our knowledge, is the first reported case from the southeast Asian region, diagnosed incidentally in a patient operated for cholelithiasis with a detailed discussion on differential considerations and comprehensive review of the literature.

\section{Case Report}

A 60-year-old female with no relevant medical history presented to the surgery outpatient department in our hospital with the complaint of a recurrent right-upper quadrant dull pain for 6 months. She had no history of fever, malaise, weight loss, lymph-

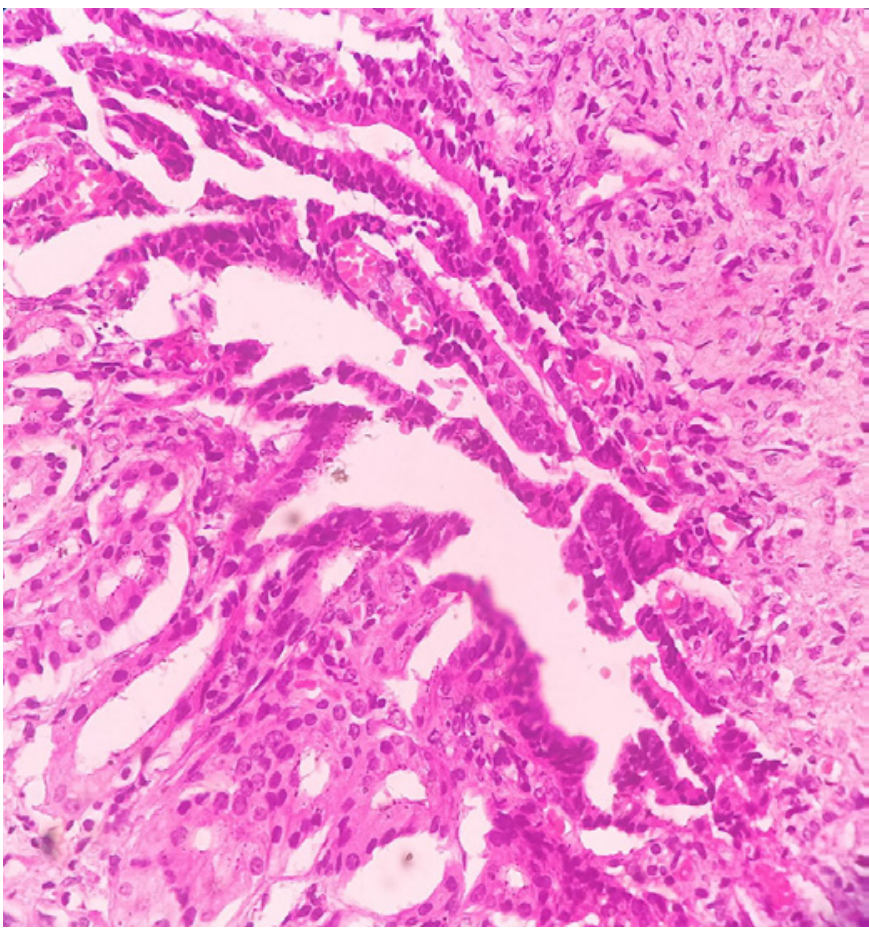

Fig. 2. Photomicrograph showing foci of conventional adenocarcinoma $(\mathrm{H} \& \mathrm{E}, \times 400)$.

adenopathy, bone pain, or any other significant manifestation indicating metastatic disease. On admission, routine hematological and biochemical tests were unremarkable other than elevation of the serum level of AFP $110 \mathrm{ng} / \mathrm{mL}$ (normal range $<10 \mathrm{ng} / \mathrm{mL}$ ).

An abdominal ultrasound revealed the presence of gallbladder calculi, with distention of the gallbladder. The patient underwent routine laparoscopic cholecystectomy for cholelithiasis in our hospital. The Glisson capsule, common bile duct, and regional lymph nodes were unremarkable. The specimen was sent for histology. On gross examination, the gallbladder measured $5.9 \times 2.8 \times 1.5 \mathrm{~cm}$. The wall was thickened, ranging from 1.2 to $1.8 \mathrm{~cm}$, maximum in the fundus region along with a brownish nodule, $1.5 \mathrm{~cm}$ in the longest axis. Cut sectioning of the nodule revealed its infiltration into the wall of the gallbladder. An attached lymph node was also seen. No evidence of necrosis or hemorrhage seen.

On microscopic examination, hematoxylin and eosin-stained sections revealed a tumor infiltrating the whole gallbladder wall, comprising solid nests and trabeculae of $>50 \%$ clear cells with abundant clear cytoplasm and well-defined cytoplasmic boundaries (shown in Fig. 1). The cells were polygonal with large hyperchromatic nuclei, distinct nucleoli in few cells, and little nuclear pleomorphism. Foci of conventional adenocarcinoma were also observed (shown in Fig. 2). The lymph node revealed no metastasis. Neural or vascular invasion was not seen. Subsequently, an immunohistochemical panel was applied including cytokeratin-7 (CK-7), carcinoembryonic antigen (CEA), cytokeratin-20 (CK20 ), AFP, and paired box gene 8 (PAX-8) to confirm the diagnosis of CCG and its AFP production as well as to rule out possible secondary deposits, particularly metastatic clear-cell renal carcinoma 

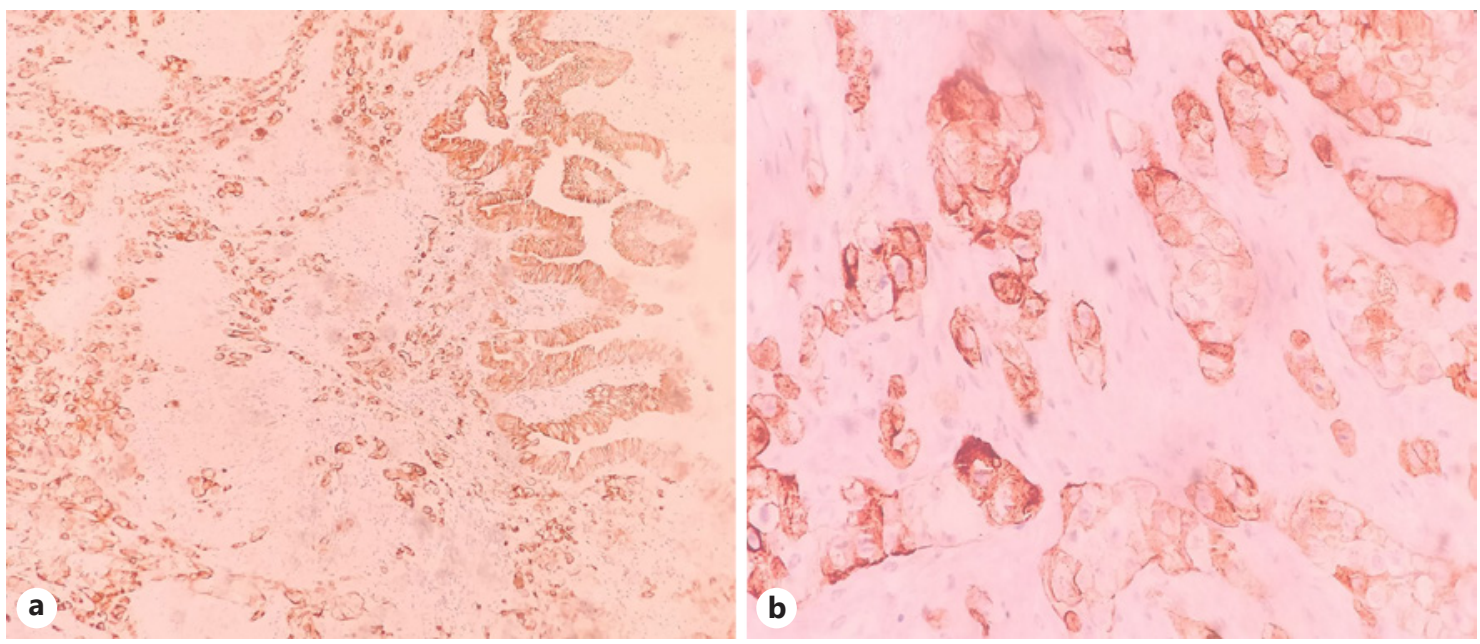

Fig. 3. Photomicrograph showing tumor cells diffuse positivity for CK-7 by IHC at low power $(\times 100)(\mathbf{a})$ and at high power $(\times 400)(\mathbf{b})$. IHC, immunohistochemistry; CK-7, cytokeratin-7.

(RCC). The tumor cells were diffusely positive for CK-7 (shown in Fig. 3a, b), partly positive for AFP (shown in Fig. 4), focally positive for CEA and CK-20, and negative for PAX-8, thus eliminating the probability of metastatic clear-cell RCC. A contrast-enhanced computed tomography (CECT) was performed, which did not reveal any mass or lesion elsewhere in the body, thereby supporting the diagnosis of primary carcinoma of the gallbladder. No evidence of residual neoplasm was observed on the CT scan. Her postoperative laboratory tests showed a decline in AFP levels to normal, respectively. The patient is currently on systemic chemotherapy and recuperating now.

\section{Discussion}

Gallbladder tumors are the fifth most common cancers of the gastrointestinal tract [8]. The most common type is adenocarcinoma of which the clear-cell type is rarely seen and was first recognized in 1986 by AlboresSaavedra and Henson [9], although in 1926, Tyson gave the first accurate description of clear-cell carcinoma of the gallbladder and designated it as hypernephroma of the gallbladder due to its similarity to renal-cell carcinoma [10]. CCG has been acknowledged as a distinct type of the gallbladder tumor by the World Health Organization (WHO), 2nd edition in 1992 [11]. An extensive study of the literature revealed $<18$ cases of CCG including the present case, reported globally in the past, out of which only Vardaman and Albores [6] and Sentani et al. [12] have encountered an AFP-producing clear-cell carcinoma of the gallbladder. Table 1 shows the list of previously reported cases of clear-cell carcinoma of the gallbladder.

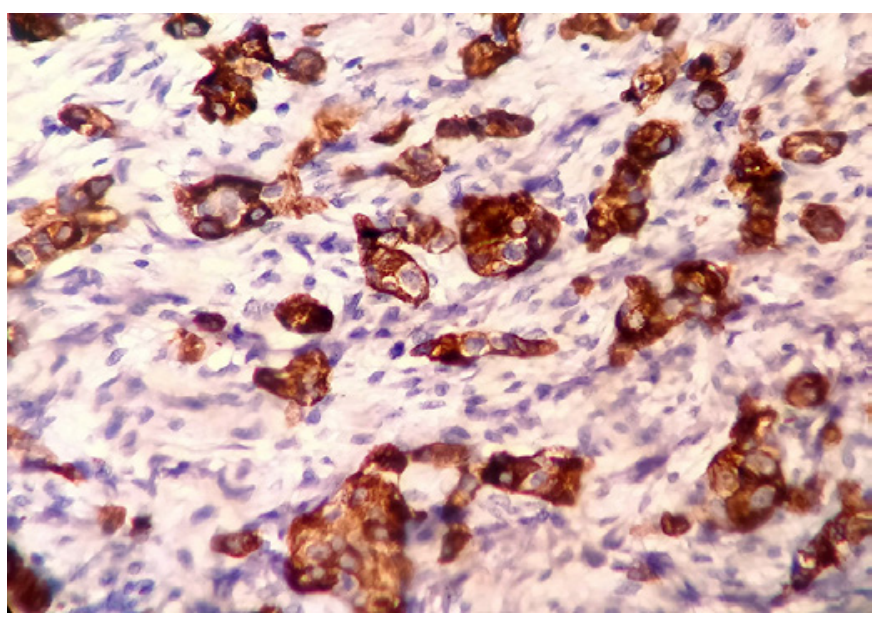

Fig. 4. Photomicrograph showing tumor cells positivity for AFP by IHC (×400). AFP, alpha-fetoprotein; IHC, immunohistochemistry.

AFP is a serum glycoprotein secreted by embryonic liver cells and yolk sac tissues and is widely utilized as a diagnostic marker for hepatocellular carcinomas or yolk sac tumors. AFP secretion by GBCs may occur given the similar embryological origin of the liver and gallbladder. The gallbladder arises from the hepatic diverticulum, which is a ventral protuberance from the caudal part of the foregut and later dissociates to form the gallbladder and liver. Due to the similar embryological origin of the liver and gallbladder, differentiation of multipotential uncommitted tumor cells in carcinoma of the gallbladder to more immature or primitive cells may invoke the AFP production $[7,12]$. 
Table 1. Previously reported cases of CCG $[5,6,8,12,14,15,24,25]$

\begin{tabular}{|c|c|c|c|c|c|c|}
\hline Author & $\begin{array}{l}\text { Number } \\
\text { of reported } \\
\text { cases }\end{array}$ & $\begin{array}{l}\text { Age } \\
\text { (years)/ } \\
\text { sex }\end{array}$ & Cholelithiasis & Histology & $\begin{array}{l}\text { Lymph node } \\
\text { metastasis }\end{array}$ & Outcome \\
\hline Maharaj et al. [5] & 1 & $56 / \mathrm{F}$ & yes & CCG & no & AWD, on CT \\
\hline Zhang et al. [14] & 1 & $80 / \mathrm{M}$ & no & CCG with hepatoid differentiation + FOCA & yes & $\begin{array}{l}19 \text { months } \\
\text { disease-free }\end{array}$ \\
\hline Eken et al. [8] & 1 & $56 / \mathrm{F}$ & no & CCG & nd & nd \\
\hline Sentani et al. [12] & 1 & $78 / \mathrm{F}$ & no & $\begin{array}{l}\text { AFP-producing CCG with neuroendocrine } \\
\text { differentiation }\end{array}$ & no & $\begin{array}{l}8 \text { months } \\
\text { disease-free }\end{array}$ \\
\hline Vaillo et al. [24] & 1 & $72 / \mathrm{F}$ & no & CCG & nd & AWD, on CT \\
\hline Piana et al. [25] & 1 & $66 / \mathrm{F}$ & yes & Combined CCG + small cell carcinoma + FOCA & no & 3 years DOD \\
\hline Bittinger et al. [15] & 3 & $53-77 / \mathrm{F}$ & yes (in 2 cases) & CCG & yes (in all cases) & nd \\
\hline $\begin{array}{l}\text { Vardaman } \\
\text { Albores-Saavedra } \\
\text { et al. [6] }\end{array}$ & 7 & $56-68 / \mathrm{F}$ & yes (in all cases) & $\begin{array}{l}\text { AFP-producing CCG and hepatoid differentiation in } \\
1 \text { case } \\
\text { Others-CCG + FOCA + areas of mucinous carcinoma } \\
\text { (in } 2 \text { cases) }\end{array}$ & yes (in 2 cases) & $\begin{array}{l}5 \text { cases-DOD } \\
2 \text { cases-AWD }\end{array}$ \\
\hline Present case & 1 & $60 / \mathrm{F}$ & yes & AFP-producing CCG + FOCA & no & AWD, on CT \\
\hline
\end{tabular}

CCG, clear-cell carcinoma of the gallbladder; FOCA, foci of conventional adenocarcinoma; ND, not determined; CT, chemotherapy; AWD, alive with disease; DOD, dead of disease; AFP, alpha-fetoprotein.

The clinical features in CCG are not different from those seen in conventional adenocarcinomas and typically presents with recurrent right upper quadrant pain, with cholelithiasis being the most frequently associated pathology, identified in association with $70-90 \%$ of gallbladder malignancies. Stones $>3 \mathrm{~cm}$ increases the risk by $9-10$ times more than stones $<1 \mathrm{~cm}[4,6]$.

Similar to other neoplasms, multiple genetic alterations play a role in the pathogenesis of GBC, which is under extensive research nowadays and has many therapeutic implications. KRAS mutation is reported in higher frequency in lesions related to pancreato-biliary maljunction than flat precursor lesions. TP53 mutation is found in approximately $27-70 \%$ of GBC. Therapeutic targeting of EGFR/HER2 pathways recognized in GBCs, with agents like erlotinib has been proved beneficial in combination with standard chemotherapeutic drugs, such as gemcitabine rather than chemotherapy alone $[3,5]$. Various other somatic mutations like NRAS, IDH2, and PIK3CA have also been detected in GBC patients [13].

Histopathologically, CCG is composed of cuboidal to polygonal clear cells with abundant cytoplasm, which is rich in glycogen in most of the cells or mucin vacuoles occasionally, little cytological atypia and few mitoses, organized in cords, trabeculae, and nests with or without glandular differentiation and displaying a solid or infiltrative growth pattern $[14,15]$. Bittinger et al. [15] suggested the term CCG to only those tumors manifesting clear cell differentiation in $>50 \%$ of tumor cells, which was encountered in our case too. Foci of classical adenocarcinoma are almost always seen in the tumor [4]. CCG must always be differentiated from other neoplasms showing clear cell features like metastatic RCC of the gallbladder [16-18], clear-cell carcinoma of the ovary [19], endometrial clearcell carcinoma [20], clear-cell variant of hepatocellular carcinoma [21], malignant clear-cell sugar tumor of the lung [22], and other tumors exhibiting clear cell differentiation (Table 2). The most important differential diagnosis comes out to be metastatic RCC. Patients with metastatic RCC of the gallbladder will have either accompanying primary renal carcinoma or a history of nephrectomy for RCC [6]. Total body imaging by contrast-enhanced computed tomography scan revealed no other lesions elsewhere, supporting the diagnosis of primary carcinoma of the gallbladder in the present case. Primary clear-cell carcinoma of the gallbladder predominantly affects women with an average age of 60 years at diagnosis, while metastatic malignancy in the gallbladder generally presents in 39-84-year-old males [16]. On histology, the points favoring primary CCG over metastatic carcinomas include the foci of conventional adenocarcinoma, adenosquamous carcinoma or mucinous carcinoma, severe dysplasia or 
Table 2. Differential diagnosis of CCG [15-21]

\begin{tabular}{|c|c|c|c|}
\hline $\begin{array}{l}\text { Other clear cell } \\
\text { tumors }\end{array}$ & $\begin{array}{l}\text { Age, } \\
\text { years/sex }\end{array}$ & Microscopy & IHC \\
\hline $\begin{array}{l}\text { Metastatic RCC } \\
{[16-18]}\end{array}$ & $39-84 / \mathrm{M}$ & $\begin{array}{l}\text { Solid, alveolar, and acinar pattern of cells with abundant clear cytoplasm } \\
\text { and central or eccentric hyperchromatic nuclei. The characteristic } \\
\text { network of small, thin-walled vasculature }\end{array}$ & $\begin{array}{l}\text { +ve for PAX-8 } \\
\text { PAX-2, CD-10, vimentin, and CA IX } \\
\text {-ve for CK-7, CK-20, and CEA }\end{array}$ \\
\hline $\begin{array}{l}\text { Clear-cell carcinoma } \\
\text { of the ovary }[15,19]\end{array}$ & $50-70 / \mathrm{F}$ & $\begin{array}{l}\text { Solid, papillary, and tubulocystic pattern lined by clear or hobnail cells. } \\
\text { Papillae are frequently hyalinized }\end{array}$ & $\begin{array}{l}\text { +ve for EMA, CK and CA-125 } \\
\text {-ve for CK-7, CK-20, and CEA }\end{array}$ \\
\hline $\begin{array}{l}\text { Endometrial clear- } \\
\text { cell carcinoma } \\
{[15,20]}\end{array}$ & $62-67 / F$ & $\begin{array}{l}\text { Solid, papillary, tubular, and cystic architecture composed of polygonal } \\
\text { cells with abundant clear or eosinophilic cytoplasm, and hobnail cells. } \\
\text { Marked nuclear atypia and high mitotic activity }\end{array}$ & $\begin{array}{l}\text { +ve for } 34 \beta E 12 \\
\text { Leu-M1, vimentin, BCL-2, CEA, P-53, } \\
\text { and CA-125 } \\
\text { ER, HER-2, and CK-7 are +/-. -ve for } \\
\text { CK-20 and PR }\end{array}$ \\
\hline $\begin{array}{l}\text { Clear-cell } \\
\text { hepatocellular } \\
\text { carcinoma }[15,21]\end{array}$ & Elderly/F & $\begin{array}{l}\text { Trabecular, acinar, or compact pattern of polygonal cells with clear, } \\
\text { vacuolated or foamy cytoplasm. Central or eccentric nucleus, frequently } \\
\text { dispersed among conventional neoplastic hepatocytes }\end{array}$ & $\begin{array}{l}\text { +ve for Hep par 1, arginase-1, and AFP } \\
\text {-ve for CK-7, CK-19, EMA, CK-20, and } \\
\text { CEA }\end{array}$ \\
\hline
\end{tabular}

CCG, clear-cell carcinoma of the gallbladder; IHC, immunohistochemistry; RCC, clear-cell renal carcinoma; CEA, carcinoembryonic antigen; CK-7, cytokeratin-7; PAX-8, paired box gene 8 .

carcinoma in situ in the adjoining mucosa, and infiltration of the mucosal layer. Restriction of metastatic carcinomas to the muscle layer and perimuscular connective tissue, and not invading the mucosa, excludes the diagnosis of metastatic carcinomas [17].

Immunohistochemistry plays a significant role in verifying the origin of clear-cell tumors. CEA and CK-7 are strongly positive in the gallbladder, but negative in almost all other carcinomas with clear cells including the kidney, liver, ovary, and endometrium. The only exception is the lung showing similar immunohistochemical staining with a slight or variable positive reaction to CEA and CK-7 [14, 15]. Furthermore, the characteristic positive staining of the clear-cell sugar tumor of the lung to human melanoma black (HMB-45), S-100, Melan-A, and microphthalmia transcription factor renders the definitive differentiation from CCG [22]. Uncommon cases of clear-cell carcinoma of the salivary glands can be confirmed by strong positive staining to S-100 protein [15]. Clear-cell carcinoid tumor of the gallbladder should also be considered a significant differential, which can be excluded by positivity for neuroendocrine markers. CCG and metastatic RCC are nonreactive to neuroendocrine markers [16].

\section{Conclusion}

The clinical and pathologic importance of AFP production by CCG has thus far remained completely obscure. However, AFP-secreting carcinomas other than hepatocellular carcinoma, hepatoblastoma, and yolk sac tumors are seldom noted and are known to have a poor prognosis with easy liver metastases. The diagnosis is usually direct in the primary tumor, but it may be troublesome in the evaluation of liver metastases [23]. Therefore, it must be remembered that serum AFP levels may also be raised in situations other than hepatocellular carcinomas or yolk sac tumors. Tumor recurrence can also be assessed by analyzing the follow-up serum AFP levels. Nevertheless, we must recognize the entity of this tumor because accurate and early diagnosis of CCG is imperative to avoid misdiagnosis as possible secondary metastasis and consequent delay in appropriate surgical therapy.

\section{Statement of Ethics}

The study was conducted ethically in accordance with the World Medical Association Declaration of Helsinki. Written informed consent was obtained from the patient for publication of this case report and any accompanying images.

\section{Conflicts of Interest Statement}

The authors declare that there are no conflicts of interest regarding the publication of this paper.
Dixit/Trivedi/Bansal 


\section{Funding Sources}

The authors did not receive any funding.

\section{Author Contributions}

N.D. and V.K.B. contributed to the acquisition of data and its interpretation. S.T. conceptualized the work and was in charge of the overall direction and planning. N.D. and V.K.B. wrote the manuscript with inputs from all authors.

\section{References}

1 Lai CHE, Lau WY. Gallbladder cancer: a comprehensive review. Surgeon. 2008;6(2):10110.

2 Zhu AX, Hong TS, Hezel AF, Kooby DA. Current management of gallbladder carcinoma. Oncologist. 2010;15(2):168-81.

3 Sharma A, Sharma KL, Gupta A, Yadav A, Kumar A. Gallbladder cancer epidemiology, pathogenesis, and molecular genetics: recent update. World J Gastroenterol. 2017;23(22): 3978-98.

4 Kanthan R, Senger JL, Ahmed S, Kanthan SC. Gallbladder cancer in the 21st century. J Oncol. 2015;2015:967472.

5 Maharaj R, Cave C, Sarran K, Bascombe N, Dan D, Greaves W, et al. A case report of the clear cell variant of gallbladder carcinoma. Int J Surg Case Rep. 2017;32:36-9.

6 Vardaman C, Albores-Saavedra J. Clear cell carcinomas of the gallbladder and extrahepatic bile ducts. Am J Surg Pathol. 1995;19(1): 91-9.

$7 \mathrm{Ng} \mathrm{WK}, \mathrm{Ng}$ WF. Elevated serum alpha-fetoprotein in a patient with undifferentiated carcinoma of the gall bladder. J Clin Pathol. 1995; 48(11):1061-3

8 Eken $\mathrm{H}$, Balci MG, Buyukakincak S, Isik A, Firat D, Cimen O. Rare tumors of the gallbladder: clear cell carcinoma. Int J Surg Case Rep. 2015;9:65-8.

9 Albores-Saavedra J, Henson DE. Tumors of the gallbladder and extrahepatic bile duct. In: Hartmann WH, editor. Atlas of Tumor Pathology. Second series, fascicle 22. Washington, DC: Armed Forces Institute of Pathology; 1986.
10 Tyson W, Piney A. Hypernephroma of gallbladder: cholecystectomy. Br J Surg. 1926; 13(52):757-9.

11 Albores-Saavedra J, Henson DE, Sobin LH. The WHO histological classification of tumors of the gallbladder and extrahepatic bile ducts. A commentary on the second edition. Cancer. 1992;70(2):410-4.

12 Sentani K, Uraoka N, Oue N, Yasui W. Alphafetoprotein-producing clear cell carcinoma of the gallbladder with neuroendocrine differentiation. Med Mol Morphol. 2014;47(1):546.

13 Sharma A, Kumar A, Kumari N, Krishnani N, Rastogi N. Mutational frequency of KRAS, NRAS, IDH2, PIK3CA, and EGFR in North Indian gallbladder cancer patients. Ecancermedicalscience. 2017;11:757.

14 Zhang C, Zhang W, Mu D, Shi X, Zhao L. A clear cell adenocarcinoma of the gallbladder with hepatoid differentiation: case report and review of literature. Onco Targets Ther. 2016; 9:5797-802.

15 Bittinger A, Altekrüger I, Barth P. Clear cell carcinoma of the gallbladder: a histological and immunohistochemical study. Pathol Res Pract. 1995;191(12):1259-65.

16 Ghaouti M, Znati K, Jahid A, Zouaidia F, Bernoussi Z, El Fakir Y, et al. A gallbladder tumor revealing metastatic clear cell renal carcinoma: report of case and review of literature. Diagn Pathol. 2013;8(1):4-49.

17 Aoki T, Inoue K, Tsuchida A, Aoki T, Kasuya $\mathrm{K}$, Kitamura K, et al. Gallbladder metastasis of renal cell carcinoma: report of two cases. Surg Today. 2002;32(1):89-92.
18 Shen SS, Truong LD, Scarpelli M, Lopez-Bel$\operatorname{tran} \mathrm{A}$. Role of immunohistochemistry in diagnosing renal neoplasms: when is it really useful? Arch Pathol Lab Med. 2012;136(4): 410-7.

19 Hammock L, Ghorab Z, Gomez-Fernandez CR, Fernandez G. Metastatic renal cell carcinoma to the ovary: a case report and discussion of differential diagnoses. Arch Pathol Lab Med. 2003;127(3):e123-6.

20 Gadducci A, Cosio S, Spirito N, Cionini L. Clear cell carcinoma of the endometrium: a biological and clinical enigma. Anticancer Res. 2010;30(4):1327-34.

21 Zimmermann A. Clear cell hepatocellular carcinoma and related tumors. Tumors and tumor-like lesions of the hepatobiliary tract. 2017. p. 215-27.

22 Olivencia-Yurvati AH, Rodriguez AE. Clear cell "sugar" tumor of the lung: benign or malignant? Int Surg. 2015;100(5):924-6.

23 Akturk G, Sagol O, Unek T, Ozbilgin M, Egeli T, Karademir S, et al. Alpha-fetoprotein-secreting gallbladder carcinoma: a case report. J Gastrointest Canc. 2018;49(4):528-31.

24 Vaíllo A, Rodríguez-Recio FJ, Gutiérrez-Martín A, Ballestín C, Ruiz-Liso JM. Fine needle aspiration cytology of clear cell carcinoma of the gallbladder with hepatic infiltration: a case report. Acta Cytol. 2004;48(4):560-4.

25 Piana S, Cavazza A, Corrado S, Putrino I, Gardini G. Combined small cell carcinoma and clear cell carcinoma of the gallbladder: report of a case and review of the literature. Pathol Res Pract. 2002;198(12):821-4. 